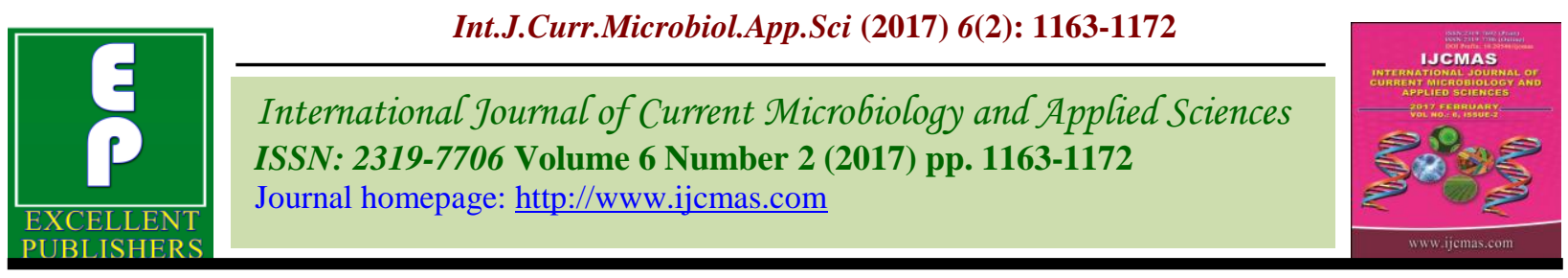

Original Research Article

http://dx.doi.org/10.20546/ijcmas.2017.602.131

\title{
Effect of Epidural Ketamine in Combination with Opioids on Haemodyanamics and Electrocardiograph in Dogs
}

\author{
R.P. Ram ${ }^{1}$, A.K. Sharma ${ }^{1}$, A.K. Anandmay ${ }^{1}$ and Raju Prasad ${ }^{2}$ \\ ${ }^{1}$ Department of Veterinary Surgery and Radiology, College of Veterinary Science and Animal \\ Husbandry, Birsa Agricultural University, Kanke, Ranchi-834006, India \\ ${ }^{2}$ Department of Pharmacology and Toxicology, College of Veterinary Science and Animal \\ Husbandry, Birsa Agricultural University, Kanke, Ranchi-834006, India \\ *Corresponding author
}

\section{A B S T R A C T}

\begin{abstract}
Keywords
Dogs, Epidural anaesthesia, Haemodynamics, Electrocardiographic changes.

Article Info

Accepted:

22 January 2017

Available Online:

10 February 2017
\end{abstract}

The objective of this study is to find out the effect of ketamine in combination of opioids on haemodynamics and electrocardiograph in dogs. The ketamine hydrochloride at $3 \mathrm{mg} / \mathrm{kg}$ bwt was administered epidurally at lumbosacrcal space in group I, whereas buprenorphine at $0.005 \mathrm{mg} / \mathrm{kgbwt}$, pentazocine at $0.3 \mathrm{mg} / \mathrm{kg}$ bwt and meperidine hydrochloride (at 1 $\mathrm{mg} / \mathrm{kgbwt}$ were given epidurally in combination with ketamine hydrochloride in group II, III and IV, respectively. To accomplish epidural block, an 18-gauge $3.5 \mathrm{~cm}$ hypodermic needle was inserted percutaneously at the prepared site into the epidural space to inject analgesic agent. Haemodynamic and electrocardiographic changes were recorded before and at the time intervals of 5, 15, 30, 60 and minutes of ketamine administration. Haemodyanamic parameters viz. heart rate, systolic arterial pressure, diastolic arterial pressure and mean arterial pressure showed a significant higher $(\mathrm{P}<0.05)$ value at initial intervals of observation, thereafter, the values revealed a decreasing trends and returned to base line value by the end of observation. Shortening of PR, R.R. and QT intervals were recorded at $5 \mathrm{~min}$ up to $30 \mathrm{~min}$. in all the groups. The QRS complex did not show significant variation among and between groups. In conclusion, ketamine in combination of buprenorphine, pentazocine and meperidine as epidural anaesthesia in dogs was found to be effective and produces reversible changes on haemodynamics and Electrocardiograph.

\section{Introduction}

One of the most useful applications of epidural analgesia is in the old dogs. When combined with effective sedation, epidural analgesia is definitely safer than general anaesthesia in old patients. Epidural analgesia can be routinely considered in all ages of dogs in select cases of caesarian section, hysterectomy, painful manipulation of the hind limbs and rectal, vaginal or perineal surgery (Booth, 1981).
Ketamine, a dissociative anaesthetic which is antagonist of N-methyl-D-aspartate (NMDA) receptors in the spinal cord. Ketamine induces local analgesia by blocking the sodium ion channels. It also interacts with opioid, monoaminergic and muscarinic receptors and voltage - gated calcium ion channels (Azari et al., 2014). Epidural ketamine alone or in combination of lidocaine or other sedatives has been reported to produce analgesia in 
human (Erol et al., 2014), ruminants (Ismail, 2016) and in cats and dogs (De Rossi et al., 2009; Abdul et al., 2015).

Buprenorphine is a derivative of the morphine alkaloid, thebaine. It is a powerful analgesic approximately 25-40 times as potent as morphine. Pentazocine is a mixed agonist antagonist opioid that appears to be 3-6 times less potent than morphine in analgesic efficacy. The most significant response of pentazocine in the dog is its effect upon systemic arterial pressure which falls by $18 \%$ following its injection (Ahlgren and Stephen, 1966). Meperidine is 5 times less potent than pentazocine. Intramuscular administration of meperidine does not significantly affect heart rate, but in administration frequently produces a marked increase in heart rate. Epidural administration of meperidine $1 \mathrm{mg} / \mathrm{kg}$ did not produce any significant change in heart rate, blood pressure and respiratory rate in adult males. The available literature suggests that only sporadic research works have been conducted in the past on the spinal use of buprenorphine (Wolff et al., 2004), morphine and pentazocine (Mohan et al., 1995) in human and epidural use of meperidine in mare (De Rossi et al., 2004). Local anaesthetic drugs administered epidurally produce sympathetic blockade and vaodilation resulting in hypotension (Cousins and Mather, 1984). When compared with other epidural administered drugs, opioids present advantages over local anaesthetic and alpha2 adrenergic agonists because motor impairment or sympathetic blockade do not occur with their use (Stoelting, 1999). The objective of this study was to comparatively evaluate the hemodynamic and electrocardiographic changes after epiduraly administration of opioids in dogs.

\section{Materials and Methods}

The present research work was conducted on 10 clinically healthy male / female mongrel dogs of about one year of age. They were divided into four groups with five dogs randomly assigned to two of four treatment groups. Each dog was subjected to two treatments of epidural analgesic administration at one week interval. The dogs were maintained in isomanagemental condition in the indoor ward of Ranchi Veterinary College clinics. Hygienic condition was maintained in and around the kennel and same type of feed was offered to each animal. Fresh water was made available freely in the kennel. All the dogs were dewormed with broad spectrum anthelmintic 7days prior to the start of experiment, respectively. The dog was kept off fed and water for 12 and 6 hours, respectively before the commencement of experiment. The ketamine hydrochloride (Ketajet ${ }^{\mathrm{R}}$-Sterkem Pharma Pvt. Ltd) at $3 \mathrm{mg} / \mathrm{kg}$ bwt was administered epidurally at lumbosacrcal space in group I, whereas buprenorphine (Bupregesic $^{\mathrm{R}}$-Neon Laboratories Ltd) at 0.005 $\mathrm{mg} /$ kgbwt, pentazocine (Fortwin ${ }^{\mathrm{R}}$-Ranbaxy Lab. Ltd) at $0.3 \mathrm{mg} / \mathrm{kg}$ bwt and meperidine hydrochloride (Demerol ${ }^{\mathrm{R}}$ - Raj Pharma, MGS Road, Patna-7) at $1 \mathrm{mg} / \mathrm{kgbwt}$ were given epidurally in combination with ketamine hydrochloride in group II, III and IV, respectively. To accomplish epidural block, an 18-gauge $3.5 \mathrm{~cm}$ hypodermic needle was inserted percutaneously at the prepared site into the epidural space to inject analgesic agent.

Haemodynamic and electrocardiographic changes were recorded before and at the time intervals of $5,15,30,60$ and minutes of ketamine administration.

Heart rate was determined with the aid of precordial stethoscope. Blood pressure $(\mathrm{mm} / \mathrm{Hg})$ was measured by using automatic NIBP machine, mean arterial pressure was measured by indirect method (Geddes et al., 1980) using formula: MAP $=$ DAP + (SAP DAP $) / 3(\mathrm{~mm} / \mathrm{Hg})$. 
Data were expressed as means $( \pm \mathrm{SE})$. The data were analyzed using ANOVA for repeated measures. Where a significant difference was indicated by ANOVA, least significant difference (LSD) test was employed as post-test. $\mathrm{P}$ value of $<0.05$ was accepted as being significant in all comparisons as described by Snedecor and Cochran (1994).

\section{Results and Discussion}

\section{Heart rate (beats/min)}

The heart rate observed in group I at different intervals of observation after epidural administration of ketamine manifested higher value even up to 120 minutes of observation. The maximum increase in heart rate in group I was recorded at 5 minutes of observation (Table-1). The values recorded at 5 and 15 minutes of observation were significantly higher as compared to the base value. The values recorded in group I at 30, 60 and 120 minutes post induction differed nonsignificantly to that of base value but varied significantly with that of value noted at 5 minutes of observation. The values recorded in group II,III and IV at the intervals of 5 and 15 minutes also showed significant variation in heart rate as compared to the value recorded at $0,30,60$ and 120 minutes of observation. The enhancement in heart rate in group was comparatively more as compared to the other treated groups. Group-wise analysis of data revealed a non-significant variation among groups.

\section{Systolic arterial pressure $(\mathrm{mm} / \mathrm{Hg})$}

The epidural administration of different anaesthetic protocols showed a significant effect on systolic arterial pressure in all the groups. Group I animals manifested a significant rise $(\mathrm{P}<0.05)$ in SAP value from 5 minutes onward till 60 minutes of observation post induction (Table-2). The maximum increase in SAP value could be recorded at 30 minutes which started declining gradually at subsequent observation period and reached to a level of nonsignificance by 120 minutes of observation. The value recorded at 5, 15 and 30 minutes differed significantly with that of values noted at 0 hour and 60 minutes. Similarly the SAP value recorded at 5, 15 and 30 minutes postinjection in group II, III and IV varied significantly as compared to there base line values. The minimum significant increase could be observed at 30 minutes (138.20 \pm 1.99) in group IV animals. Group-wise analysis of data did not reveal any significant variation among groups.

\section{Diastolic arterial pressure $(\mathrm{mm} / \mathrm{Hg})$}

The diastolic arterial pressure in all the groups following administration of different drug schedule epidurally exhibited a significant rise $(\mathrm{P}<0.05)$ as compared to their respective pre induction value (Table-3). Group I,III and IV showed significant rise in DAP value up to 30 minutes of observation while in group II, it could be recorded up to 15 minutes post induction. The initial hike in DAP value started decreasing gradually and reached to a level of non significance by 120 minutes of observation. The maximum increase in DAP level could be observed at 30 minutes of observation in group I while in group II,III and IV, it could be recorded at 15 minutes post injection. The different drug schedule administered did not show any significant effect among groups.

\section{Mean arterial pressure $(\mathrm{mm} / \mathrm{Hg})$}

Increasing trend at initial intervals followed by decreasing trend towards the respective base value was a consistent feature in all the groups. These variations were within the normal physiological limits. The increased 
level in MAP was recorded up to 60 minutes of observation in group I as compared to its base value. The maximum level of MAP was recorded at 30 minutes interval in group $\mathrm{I}$. Though the mean arterial pressure was significantly higher $(\mathrm{P}<0.05)$ at 60 minutes of observation as compared to its base value but a declining trend was conspicuous from 60 minutes and the value reached to pre-injection level by 120 minutes of observation (Table4). The animals of group II, III and IV also showed the significantly higher level of MAP at 5, 15 and 30 minutes intervals of observation as compared to their base values. The values recorded at 60 minutes in group II and IV did not differ significantly as compared to their baseline value, whereas, it was significantly higher in group III at corresponding period of observation. The values recorded at 120 minutes of observation were non-significantly higher as compared to the base values in all the groups. There was non-significant correlation among groups at corresponding intervals of observation

\section{Electrocardiographic changes}

The cardiac rhythm presented was sinus rhythm with tachycardia in the animals of all the groups. A remarkable changes were found at different periods of observation in the interval and amplitude of ECG in all the groups but the maximum variation was recorded in group-I. A sinus arrhythmia was a transient finding in all the groups after administration of anesthetics. There were shortening of PR intervals, QT intervals up to 120 minutes of observation in group I. The maximum shortening in PR, QT and RR intervals were recorded at 5 min after administration of ketamine anesthesia. The QRS complex did not revealed any significant changes. The ST segment was deviated in two animals and biphasic $\mathrm{P}$ waves were found in one dog before as well as after the administration of drugs. A slight shortening of PR, RR, and QT intervals were also found in group II, III and IV as compared to dogs of group I. The ST segments were depressed in the one dog of group III. The diaphasic or two peak pattern of the $\mathrm{T}$ wave was associated with the decreased amplitude in two animals of group-I

The heart rate observed in all the groups, after epidural administration of analgesic drugs, manifested higher value at initial intervals of observation. This increase in heart rate might be sequel to rapid absorption and systemic distribution of drugs from epidural space. A significant increase in heart rate after epidural administration of ketamine has also been reported by Aithal et al. (1998). A major feature that distinguishes ketamine from other intravenous anaesthetics is stimulation of the cardio vascular system (Reich and Silvay, 1989). Ketamine causes increase in arterial pressure, heart rate and cardiac output in a man after intravenous infusion (Idvall et al., 1979).

Ketamine has unusual pressure effects like increased blood pressure and heart rate at lower dose levels $(2-5 \mathrm{mg} / \mathrm{kg})$ and at higher doses $(10-20 \mathrm{mg} / \mathrm{kg})$ produces depressor effects more similar to those induced by other anaesthetic agents (Parker and Adams, 1978). Sharma et al. (2005) also recorded increased heart rate from 5 to 90 minutes after epidural administration of buprenorphine and ketamine in atropinized dog. Buprenorphine administration as an intravenously in rabbits increased arterial blood pressure and did not change the heart rate. Buprenorphine hydrochloride is a partial agonist with a very high affinity for opioid receptors with a potency of about 25-50 times more than that of equivalent quantity of morphine sulphate (Kay, 1978). It has slow onset and longer duration of action about 6 to 8 hours. Amarpal et al. (1997) noticed significant increase in heart rate following epidural administration of pethidine and ketamine in dogs. 
Heart rate and blood pressure did not change significantly in dogs treated with meperidine and acepromazine (Gomes et al., 2011) and in horse treated with epidural meperidine (De Rossi et al., 2004). Increase in heart rate in meperidine group might be due to its atropine like action (Kumar et al., 1988). Bradycardia occurring following opioids administration has been compensated and antagonized by epidural administration of ketamine causing tachycardia (Sharma et al., 2005). Nonsignificant change in heart rate has been reported in horse after epidural administration of meperidine (Skarda et al., 2001), in dog treated with buprenorphine and acepromazine (Stepien et al., 1995) and in man after epidural administration of meperidine and pentazocine (Mohan et al., 1995).

\section{Haemodynamic changes [(Systolic arterial pressure (SAP)/Diastolic arterial pressure (DAP)/Mean arterial pressure (MAP)]}

An Increasing trend at initial intervals following epidural administration of different drug combinations could be observed in all the groups. However, the alteration in haemodynamic profiles were transient and the values returned towards preinjection level by 120 min of observation which is suggestive of that the effect of analgesic drugs, used epidurally, on haemodynamic profiles is short lived and of no consequence. A significant increase in SAP and DAP typically occur after intravenous or intramuscular administration of ketamine (Wright, 1982; White et al., 1982). The increase in DAP and SAP with faster rate as compared to other groups might be due to rapid distribution to the plasma and cerebrospinal fluid from epidural space (Pedraz et al., 1991). The increase with slower rate in other groups except ketamine might be due to cardiovascular depression property of opioids which antagonises the effect of ketamine. Intravenous administration of buprenorphine in rabbits increased the arterial blood pressure (Kay, 1978). Meperidine is anticholinergic agent therefore in association with ketamine, it produces synergistic effect in increasing the SAP, DAP and MAP. Mean arterial pressure showed a slight increase in women after epidural administration of meperidine (Khaw et al., 2000). Pethidine and pentazocine increase the heart rate and systemic arterial pressure after its use in myocardial infarction in man (Lee et al., 1976; Nagle and Pilcher, 1972). This increase in systemic arterial pressure was assumed to be caused by peripheral resistance. Levitsky et al. (1971) in an experiment on dogs have shown that pethidine and pentazocine have a positive inotropic effect. No significant difference in HR, MAP, SAP and DAP could be observed at any interval of observation after epidural ketamine in dogs (Rao et al., 1998). Mohan et al. (1995) did not observe significant change in blood pressure after epidural administration of meperidine and pentazocine in man.

Numerous investigators have reported an increase in heart rate, systemic arterial pressure, systemic vascular resistance, pulmonary arterial pressure and pulmonary vascular resistance after ketamine administration (Folts et al., 1975; Kerr et al., 2004). This increase in cardiovascular parameters may be due to direct negative inotropic which effect is usually overshadowed by central sympathetic stimulation. This is further supported by the fact that circulatory catecholamine level is increased at least partially by inhibition of reuptake (Lundy et al., 1986). Control inhibition of catecholamine reuptake may also contribute to ketamine for cardio vascular stimulation. 
Table.1 Mean \pm S.E value of heart rate (beats / min) of different groups at different time intervals of observation

\begin{tabular}{|c|c|c|c|c|c|c|}
\hline \multirow{2}{*}{ Group } & \multicolumn{7}{|c|}{ Period of observation (in minutes) } \\
\cline { 2 - 7 } & $\mathbf{0}$ & $\mathbf{5}$ & $\mathbf{1 5}$ & $\mathbf{3 0}$ & $\mathbf{6 0}$ & 120 \\
\hline I & $92.40 \pm 1.46^{\mathrm{aA}}$ & $100.80 \pm 0.77^{\mathrm{bA}}$ & $101.20 \pm 0.91^{\mathrm{bA}}$ & $100.40 \pm 0.83^{\mathrm{bA}}$ & $94.00 \pm 1.17^{\mathrm{aA}}$ & $93.40 \pm 4.09^{\mathrm{aA}}$ \\
\hline II & $91.80 \pm 0.52^{\mathrm{aA}}$ & $98.60 \pm 1.82^{\mathrm{bA}}$ & $97.80 \pm 0.44^{\mathrm{bcA}}$ & $94.00 \pm 1.65^{\mathrm{aAA}}$ & $93.80 \pm 1.91^{\mathrm{acA}}$ & $92.80 \pm 0.66^{\mathrm{aA}}$ \\
\hline III & $92.00 \pm 3.01^{\mathrm{aA}}$ & $100.40 \pm 0.46^{\mathrm{bA}}$ & $101.00 \pm 0.40^{\mathrm{bA}}$ & $95.20 \pm 0.87^{\mathrm{aA}}$ & $94.60 \pm 1.08^{\mathrm{aA}}$ & $93.40 \pm 1.61^{\mathrm{aA}}$ \\
\hline IV & $92.40 \pm 1.08^{\mathrm{aA}}$ & $101.80 \pm 0.95^{\mathrm{bA}}$ & $102.20 \pm 1.04^{\mathrm{bA}}$ & $95.80 \pm 0.72^{\mathrm{cA}}$ & $95.00 \pm 0.85^{\mathrm{acA}}$ & $94.00 \pm 1.17^{\mathrm{acA}}$ \\
\hline
\end{tabular}

Values with same superscripts in a column (capital letters) did not differ significantly.

Values with same superscripts in a row (small letters) did not differ significantly.

Table.2 Mean \pm S.E value of systolic arterial pressure $(\mathrm{mm} / \mathrm{Hg})$ of different groups at different time intervals of observation

\begin{tabular}{|c|c|c|c|c|c|c|}
\hline \multirow{2}{*}{ Group } & \multicolumn{7}{|c|}{ Period of observation (in minutes) } \\
\cline { 2 - 7 } & $\mathbf{0}$ & $\mathbf{5}$ & $\mathbf{1 5}$ & $\mathbf{3 0}$ & $\mathbf{6 0}$ & $\mathbf{1 2 0}$ \\
\hline I & $133.80 \pm 0.52^{\mathrm{aA}}$ & $144.00 \pm 0.28^{\mathrm{bA}}$ & $146.00 \pm 1.20^{\mathrm{bA}}$ & $146.80 \pm 0.72^{\mathrm{bA}}$ & $139.80 \pm 2.39^{\mathrm{CA}}$ & $134.40 \pm 1.00^{\mathrm{aA}}$ \\
\hline II & $131.80 \pm 0.59^{\mathrm{aA}}$ & $142.00 \pm 1.70^{\mathrm{bA}}$ & $143.20 \pm 0.82^{\mathrm{bA}}$ & $140.00 \pm 3.48^{\mathrm{bA}}$ & $134.40 \pm 0.67^{\mathrm{AA}}$ & $132.60 \pm 0.46^{\mathrm{AA}}$ \\
\hline III & $132.80 \pm 1.25^{\mathrm{aA}}$ & $143.00 \pm 1.02^{\mathrm{bA}}$ & $143.40 \pm 0.61^{\mathrm{bA}}$ & $140.80 \pm 2.57^{\mathrm{bA}}$ & $136.00 \pm 0.85^{\mathrm{aA}}$ & $134.60 \pm 1.19^{\mathrm{aA}}$ \\
\hline IV & $132.00 \pm 0.49^{\mathrm{aA}}$ & $145.80 \pm 0.59^{\mathrm{bA}}$ & $146.00 \pm 0.85^{\mathrm{bA}}$ & $138.20 \pm 1.99^{\mathrm{bA}}$ & $134.20 \pm 1.07^{\mathrm{aA}}$ & $133.60 \pm 0.92^{\mathrm{AA}}$ \\
\hline
\end{tabular}

Values with same superscripts in a column (capital letters) did not differ significantly.

Values with same superscripts in a row (small letters) did not differ significantly.

Table.3 Mean \pm S.E value of diastolic blood pressure $(\mathrm{mm} / \mathrm{Hg})$ of different groups at different time intervals of observation

\begin{tabular}{|c|c|c|c|c|c|c|}
\hline \multirow{2}{*}{ Group } & \multicolumn{7}{|c|}{ Period of observation (in minutes) } \\
\cline { 2 - 7 } & $\mathbf{0}$ & $\mathbf{5}$ & $\mathbf{1 5}$ & $\mathbf{3 0}$ & $\mathbf{6 0}$ & $\mathbf{1 2 0}$ \\
\hline I & $86.80 \pm 0.33^{\mathrm{aA}}$ & $93.60 \pm 1.22^{\mathrm{bA}}$ & $94.20 \pm 2.78^{\mathrm{bA}}$ & $94.60 \pm 0.46^{\mathrm{bA}}$ & $89.80 \pm 1.04^{\mathrm{abA}}$ & $87.00 \pm 1.02^{\mathrm{aA}}$ \\
\hline II & $86.6 \pm 0.83^{\mathrm{aA}}$ & $93.2 \pm 2.49^{\mathrm{bA}}$ & $93.4 \pm 1.22^{\mathrm{bA}}$ & $90 \mathrm{a} \pm 1.13^{\mathrm{aA}}$ & $89.2 \pm 1.63^{\mathrm{abA}}$ & $87.2 \pm 1.18^{\mathrm{abA}}$ \\
\hline III & $87.20 \pm 0.52^{\mathrm{aA}}$ & $93.80 \pm 2.0^{\mathrm{bcA}}$ & $94.60 \pm 0.88^{\mathrm{bA}}$ & $93.80 \pm 1.00^{\mathrm{bCA}}$ & $90.00 \pm 1.4^{\mathrm{acA}}$ & $88.20 \pm 0.33^{\mathrm{aA}}$ \\
\hline IV & $87.40 \pm 0.46^{\mathrm{aA}}$ & $94.00 \pm 1.55^{\mathrm{bA}}$ & $94.60 \pm 0.61^{\mathrm{bA}}$ & $93.87 \pm 1.79^{\mathrm{bA}}$ & $90.03 \pm 1.61^{\mathrm{abA}}$ & $89.20 \pm 2.90^{\mathrm{abA}}$ \\
\hline
\end{tabular}

Values with same superscripts in a column (capital letters) did not differ significantly.

Values with same superscripts in a row (small letters) did not differ significantly. 
Table.4 Mean \pm S.E value of mean arterial pressure $(\mathrm{mm} / \mathrm{Hg})$ of different groups at different time intervals of observation

\begin{tabular}{|c|c|c|c|c|c|c|}
\hline \multirow{2}{*}{ Group } & \multicolumn{6}{|c|}{ Period of observation (in minutes) } \\
\cline { 2 - 7 } & $\mathbf{0}$ & $\mathbf{5}$ & $\mathbf{1 5}$ & $\mathbf{3 0}$ & $\mathbf{6 0}$ & 120 \\
\hline I & $102.59 \pm 0.25^{\mathrm{aA}}$ & $110.40 \pm 0.84^{\mathrm{bA}}$ & $111.47 \mathrm{~b} \pm 2.01^{\mathrm{bA}}$ & $111.99 \pm 0.13^{\mathrm{bA}}$ & $106.99 \pm 0.53^{\mathrm{cA}}$ & $102.76 \pm 0.80^{\mathrm{aA}}$ \\
\hline II & $101.40 \pm 0.50^{\mathrm{aA}}$ & $109.03 \pm 0.99^{\mathrm{bA}}$ & $109.53 \pm 0.59^{\mathrm{bA}}$ & $107.33 \pm 1.9 \mathrm{~b}^{\mathrm{cA}}$ & $104.5 \pm 1.18 \mathrm{a}^{\mathrm{cA}}$ & $102.27 \pm 0.8^{\mathrm{aA}}$ \\
\hline III & $102.21 \pm 0.49^{\mathrm{aA}}$ & $110.71 \pm 1.15^{\mathrm{bA}}$ & $110.84 \pm 0.45^{\mathrm{bA}}$ & $109.89 \pm 0.4^{\mathrm{bcA}}$ & $104.67 \pm 0.25^{\mathrm{cA}}$ & $103.73 \pm 0.17^{\mathrm{aA}}$ \\
\hline IV & $102.39 \pm 0.44^{\mathrm{aA}}$ & $111.19 \pm 1.07^{\mathrm{bA}}$ & $111.81 \pm 0.60^{\mathrm{bA}}$ & $108.57 \pm 1.51^{\mathrm{bA}}$ & $103.97 \pm 0.93^{\mathrm{aA}}$ & $104.47 \pm 1.79^{\mathrm{aA}}$ \\
\hline
\end{tabular}

Values with same superscripts in a column (capital letters) did not differ significantly.

Values with same superscripts in a row (small letters) did not differ significantly.

Electrocardiographic monitoring gives an accurate indication of changes in cardiac rate and rhythm. The displacement of ST segment in two dogs have been due to hypotension (Freeman, 1962) is known to indicate the occurrence of functional myocardial changes caused by reduced coronary blood flow. Minimum arrhythmia was also reported in acepromazine, opioids and ketamine anaesthesia (Atalan et al., 2002). Tachycardia at initial intervals was remarkable finding in all the groups as evidences by shortening of PR, RR and QT intervals. This is in agreement with Tanabe and Nio (1970) who reported no arrhythmia but only tachycardia after ketamine anaesthesia. A slight increase in PR and QT intervals in groups II, III and IV may be due to cardiovascular depression of opioids which antagonized by ketamine. Opioids can indirectly alter cardiac function via inhibitory actions on the autonomic and central nervous systems. Furthermore, opioids may alter cardiac contractibility directly via activation of opioid receptors and by membrane interactions because of their chemical properties and structures (Kanaya et al., 1998). Ketamine has sympathomimetic and antiarrhythmic activity. The changes in electrocardiograph returned towards normalcy during recovery from anaesthesia concurrent with the findings of Tachibana et al. (1966).
Authors' contribution: RPR and AKS have designed and conducted the research work. AKA has helped in estimation and collection of materials and RP has involved in suggestion, statistical analysis and drafting of manuscript.

Acknowledgement: Authors are very thankful to our Director Research, Birsa Agricultural University and Dean, College of Veterinary and Animal Husbandry, Kanke, Ranchi for providing requisite facilities and financial assistance to carry out the research work.

Competing interest: Authors have no competing interest regarding publication of manuscript.

\section{References}

Abdul, A.A., Gabrel, D., Sadiqy, A. Moblazi, L.F. and Unoruoyiza, M.M. 2015. Lumbosacral epidural analgesia with ketamine alone with combination with xylazine in dogs. International J. Vet. Sci., 4(3):111-117.

Aithal, H.P., Amarpal, Singh, G.R. 1998. Epidural use of ketamine for hindquarter analgesia in dogs. Indian J. Animal Sci., 68(6): 554. 
Amarpal, Aithal, H.P., Kinjavdekar, P. and Singh, G.R. 1997. Clinical effects of epidural ketamine and pethidine in dogs. 21 Annual Congress of I.S.V.S., Palampur, Abstract no. 30.

Atalan, G., Uzun, M., Demirkan, I., Yildiz, S., and Cenesiz, M. 2002. Effect of Medetomidine-Butorphanol-Ketamine Anaesthesia and Atipamezole on Heart and Respiratory Rate and Cloacal Temperature of Domestic Pigeons. J. Vet. Med., A 49 (6):281-285.

Booth, N.H. 1981. Veterinary Pharmacology and Therapeutics, 4th edn., ed. by L. Mayer Jones, Nicholas H. Booth, W. Both, Leslie E. McDonald. Oxford \& IBH Published Co. New Delhi, Bombay \& Calcuta. 436-445.

Cousins, M.J. and Mather, L.E. 1984. Intrathecal and epidural administration of opioids. Anesthesiol., 61(3):276-310.

De Rossi, R., Sampaio, B.F.B., Varela, J.V. and Junqueira, A. L. 2004.Perineal analgesia and hemodynamic effects of the epidural administration of meperidine or hyperbaric bupivacaine in conscious horse. Canadian Vet. J., 45(1):42-47.

DeRossi, R., Benites, A.P., Ferreira, J.Z., Neto, J.M. and Hermeto, L.C. 2009. Effects of lumbosacral epidural ketamine and lidocaine in xylazinesedated cats. J. S. Afr. Vet. Assoc., 80: 79-83, 2009.

Erol, I.M., Özdogan, L., Örnek, D., Tas, V., Kalayc1, D., Barçın, S., Sahin,F., Erk, G.and Dikmen, B. 2014. Effect of ketamine on the quality of anesthesia and postoperative analgesia in epidural anesthesia. JECM, 6: 83-89.

Folts J.D., Afonso, S. and Rowe, G.G.1975.Systemic and coronary haemodynamic effects of ketamine in intact anaesthetized and unanaesthetized dogs. Br. J. Anaesth., 47(6):686-94.

Freeman, J. 1962. Survival of bled dogs after halothane and ether anaesthesia. Br. J. Anaesth.,34: 832

Geddes, L.A., Combs, W. and Denton, W. 1980. Indirect mean arterial pressure in the anaesthetized dog. Am. J. Physiol., 238: $664-666$.

Gomes, V.H. , Monteiro, E. R., Dias R. S., Sá de Oliveira, R.L., Albuquerque da Silva, M. F., and Coelho, K. 2011. Comparison of the sedative effects of morphine, meperidine or fentanyl, in combination with acepromazine, in dogs. Ciencia Rural, Santa Maria, 41(8): 1411-1416.

Idvall, J., Ahlgren, I., Aronsen, K.R. and Stenber, G.P. 1979. Ketamine infusions: pharmacokinetics and clinical effects. British J. Anaesthesiol., 51: 1167-1173.

Ismail, Z.B. 2016. Epidural analgesia in cattle, buffalo, and camels. Vet. World, 9(12): 1450-1455.

Kay, B., Keaney, J. P.D. and Taylor, G.J. 1970. Neuroleptanalgesia:A double blind comparison of pentazocine and phenoperidine for neuroradiological investigations. J. Anesth., 42: 329.

Kay, B.A. 1978. A double blind comparison of morphine and buprenorphine in the prevention of pain after operation. $B r . J$. Anaesth., 50: 605-8.

Kerr, C.L., Mc Donell, W. N. and Young, S. S. 2004. Cardiopulmonary effects of romifidine/ketamine xylazine/ketamine when used for short duration anaesthesia in the horse. Can. J. Vet. Res., 68(4): 274-282.

Khaw, K.S., Ngan, Kee, W.D., Critchley, L.A. 2000. Epidural meperidine does not cause hemodynamic changes in the term parturient. Can. J. Anaesth., 47(2): $155-9$.

Kumar, A., Jadon, N.S. and Singh, B. 1988. Neuroleptanalgesia with meperidine and promazine in dogs. Indian vet. J., 65(2): 126-132. 
Lee, G., DeMaria, A.N., Amsterdam, E.A., Realyvasquez,F., Angel,J., Morrison S. and Mason, D.T.1976.Comparative effects of morphine, meperidine and pentazocine on cardiocirculatory dynamics in patients with acute myocardial infarction. Am. J. Med., 60(7): 949-55.

Levitsky, S., Mullin, E.M., Sloane, R.E., and Morrow, A.G. 1971. Experimental evaluation of pentazocine. Effect on myocardial contractility and peripheral vascular resistance. American Heart J., (81): 38I.

Lundy, P.M., Lockwood, P.A., Thompson, G. and Frew, R. 1986. Differential effects of ketamine isomers on neuronal and extraneuronal catecholamie uptake mechanisms. Anesthesiol., 64: 359-3.

Mohan, V.K., Batra, Y.K., Vaidyanathan, S., and Puri, G.D. 1995. Analgesic and urodynamic effects of epidural meperidine and pentazocine, a comparative study. Int. J. Clin. Pharmacol. Ther., 33(1): 34-37.

Nagle, R.E. and Pilcher, J. 1972. Respiratory and circulatory effects of pentazocine review of analgesics used after myocardial infarction. British Heart J., 34: 244-251.

Noriaki Kanaya, N., Zakhary, D.R., Murray, P.A. and Damron, D.S. 1998. differential Effects of Fentanyl and Morphine on Intracellular $\mathrm{Ca}^{2+}$ Transients and Contraction in Rat Ventricular Myocytes. Anesthesiol., 89(12): 1532-1542.

Parker, J.L. and Adams, H.R. 1978. The influence of chemical restraining agents on cardiovascular function. Laboratory Animal Sci., 28: 575.

Pedraz, J.I., Calvo, M.B., Gascon, A.R., Hernandez, R., Muriel, C. and Torres, L.M.1991. Pharmacokinetics and distribution of ketamine after extradural administration to dogs. Br. J. Aneasth.,
67: 310-316.

Rao, K.N.M., Rao, K.V., Makkena, S. and Naidu, K.S. 1999. Ketamine as an epidural anaesthetic in dogs. Indian Veterinary J., 76: 61-61.

Reich, D.L. and Silvay, G. 1989. Ketamine:an update on the first 25 years of clinical experience. Canadian J. Anaesthesiol., 36: 186-197.

Sharma, Y.K., Pandey, S.S., Pandey, S.K. and Sharma, R.K. 2005.Clinicophysiological effects of epidural buprenorphine in combinations with bupivacaine, xylazine or ketamine in dogs. Indian J. Vet. Surg., 26 (1): 43-44.

Skarda, R.T. and Muir, W.W.2000.Analgesic, hemodynamic, and respiratory effects induced by caudal epidural administration of meperidine hydrochloride in mares. Am. J. Vet. Res., 62(7):1001-7.

Snedecor, G.W. and Cochran, W.G. 1994. Statistical methods 8th Edn. Iowa State University Press, Ames, Iowa

Stepien, R.C., Bonagura, J.D. and Bednarbki, R.M.1995. Cardiorespiratory effects of acepromazine maliate and buprenorphine hydrochlonde in clinically normal dogs. Am. J. Vet Res., 56: 78-84.

Stoelting, R.K. 1999. Pharmacology and Physiology in Anesthetic Practice, ed 3. Philadelphia, Lippincott-Raven Publishers, pp.77112.

Tachibana, N., Morikawa, K. Yanagida, N., Fuchita, H. and Yamamura, H. 1966. Clinical experience of 2- (ochlorphenyl)- 2- methyle - amino cyclohexanone CI-581. Jap. J. Anaesth., 15: 1323.

Tanabe, R. and Nio, K. 1970. Clinical experiences with ketamine hydrochloride. Hiroshima J. Anaesth., 6: 125 . 
White, P.F., Way, W.L., Trevor, A.J. 1982. Ketamine - its pharmacology and therapeutic uses. Anaesthesiol., $56: 119$.

Wolff, M., Olschewski, A., Vogel, W. and Hempelmann, G. 2004. Meperidine Suppresses the Excitability of Spinal
Dorsal Horn Neurons. Anaesthesiol., 100: 947-55.

Wright, M. 1982. Pharmacologic effects of ketamine and its use in veterinary medicine. J. Am. Vet. Med. Assoc., 180: 1462-1471.

\section{How to cite this article:}

Ram, R.P., A.K. Sharma, A.K. Anandmay and Raju Prasad. 2017. Effect of Epidural Ketamine in Combination with Opioids on Haemodyanamics and Electrocardiograph in Dogs. Int.J.Curr.Microbiol.App.Sci. 6(2): 1164-1172. doi: http://dx.doi.org/10.20546/ijcmas.2017.602.131 